\author{
S.A. Baimamyrov, B.K. Tungushbaeva \\ Karaganda technical university, Karaganda, Kazakhstan \\ (E-mail: baymamyrov.serikkazy@mail.ru,b.tungushbaeva@gmail.com)
}

\title{
Objectification of the superconcept «ideology» in the publicistic discours: diachronic aspect
}

\begin{abstract}
The authors considers the phraseological - periphrastic combination in the conceptospher of the superconcept «ideology» that exist in the minds of members of social groups in the form of linguistic representations, define group identity and are included in the body of political lexicon, as one of the highlights of the Russian language will the Soviet / post-Soviet period. Our research is devoted to an actual problem of the modern linguistic science - cognitive theory, particularly to structure and semantic study of the superconcept «ideology». In the article described over phrase combinations OPHC of the Russian language, verbalizing this concept in publicistic discourse of the Soviet and beginning of the Post Soviet periods. Theoretical importance of the offered research is defined by the development of the Russian language conceptosphere theory, author's attempt to work out $\mathrm{OPhC}$ theory, ordering principles, underlining and describing them in pragma linguistic aspectpractical. The authors of the article also present various schemes and tables, illustrating the theoretical provisions of the work.
\end{abstract}

Keywords: language, ideology, linguistic representations, political lexicon, conceptosphere, social groups, publicism.

One of the most serious problems of the modern linguistic science is the problem of the historical judgment of the Russian language development in the twentieth century.

Many peculiar features of the Russian language of the twentieth century, especially its lexicology, formed under the powerful influence of the communist ideology, functioning of the language depended on the Soviet language picture of the world, which wasn't always adequate reflection of the real world picture. Each language reflects certain, specific to it, way of perception and organization (conceptualization) of the world, direction and character of the conceptualization itself are culturally determined. Given statement related to the number of more essential in linguistics dates back to V. fon Humboldt, A.A. Postebni, Sh.Balli, E.Sepir, B.L. Uorph and others work. Process (and result) of the language conceptualization is understood in modern linguistics as a verbal registration of «accumulated» by human sense meanings and structurization of the knowledge about the world on the data basis of the language. Language provides the most natural access to consciousness and thought processes, not only for many results of the mental process turned out to be verbalized, but for «we know about consciousness structured only owing to the language, which lets to report about these structures and describe them in any natural language « $[1 ; 21]$.

In cognitive linguistics scientists study a large number of problems, connected with solving of the main goal of the given synthetic discipline, studying, in particular, «mental» basis of understanding and producing (generation) of speech, «language knowledge» in the process of transference and processing information about the world, processes of conceptualization and categorization.

Knowledge about the world is accumulated in mental formations-concepts. So in cognitive science affirmed the opinion to consider concept as multidimensional formation, having certain structure, including not only notion and definition but connotative, figurative, estimative, associative characteristics, as one of the actual problems of the modern linguistic science is language study of the Soviet period, defining it's place in historical development of the Russian language, research of structure and semantic space of superconcept IDEOLOGY seems perspective, so this construct is a main in the Russian conceptual picture of the world of the Soviet period.

Our research is devoted to an actual problem of the modern linguistic science - cognitive theory, particularly to structure and semantic study of the superconcept IDEOLOGY. In the article described over phrase combinations OPHC of the Russian language, verbalizing this concept in publicistic discourse of the Soviet and beginning of the Post Soviet periods.

Exclusive ideologizing of publicistics, forcing to only possible interpretation of facts, phenomena, events is a characteristic feature of the Soviet period of time. Only in discourse formed communication be- 
tween language and ideology, to the later submitted realization of the language means choice, influencing to pragmatical information $\mathrm{OPhC}$ appeared in party leaders and activists speech, spread through newspapers, reports at the meetings, decisions and and orders became speech samples for wide strata of population. It is possible to consider $\mathrm{OPhC}$ as microconcepts' language realization defining base concepts volume on different conceptual lines in the structure of the superconcept IDEOLOGY, acting as an integration meaning centre connected by general semantics of the lexical elements. Object of research: phrazeologized and over phrased combinations (OPhC), objecting superconcept IDEOLOGY in Soviet publicistic discourse, subject of study OPhC concentual-semantic, structural pecularities.

Scientific novelty is the description of specific lexical units of the Soviet time, publicistic discourse phraseologised over phrased combinations as organizing semantic space of super concept IDEOLOGY in the Russian language of the Soviet and PostSoviet periods. Analyzed cognitive - semantic paradigm of the initial superconcept and in it base concepts structure, carried out research of $\mathrm{OPhC}$ verbalizing given paradigm in pragama linguistic aspect.

Theoretical importance of the offered research is defined by the development of the Russian language conceptosphere theory, author's attempt to work out $\mathrm{OPhC}$ theory, ordering principles, underlining and describing them in pragma linguistic aspectpractical-is in: data of conducted research can be used in the practice of teaching course «History of the Russian literary language» and special courses on actual problems of the modern linguistics (cognitive linguistics, intercultural communications, linguaculturology, pragma linguistics), in training the Russian language as a foreign, for compiling educational phraseologized over phased combinations dictionary of Soviet and Post-Soviet periods Research material is taken at the result of choice out from the numbers of the newspaper «Pravda», volume - 733 phraseologized over phased combinations (390 OPhC dated to $1985,343 \mathrm{OPhC}$ to 1993). Material source - numbers of the newspaper «Pravda», dated to 1985, which was the beginning of the radical state transformations in the history of the USSR and 1993 noted by transformation of the existed political system. Urgency, interest to publicistic discourse (newspaper language) are determined, as B.Zh. Raimbekova writes, by that: First newspaper language is most mobile Stylistic subsystem of the literary language, dynamically reflects all new formations, appeared in the language due to various reasons.

At first innovations appear in newspaper language, then they fixed or disappear. Secondly, during cardinal historical changes; lexical and phraselogical language, fund updated, old destructed, formed new neutral background new semantic oppositions appear [2; 4].

Lexical units of the Soviet period OPhC are non-uniform in their structure, lets to speak about their structural classification. Hidden, veiled forms of authorative influence entirely depend on strategy and tactics of the authorative person. If orders, instructions are strategy and tactics result of direct pressure and pressing, hidden forms of pressure and pressing realized more often through instructions on status, unequality of communicated according to existed classification in linguistics, integratures concepts are divided into: micro -base, macro and superconcepts, consisting conceptosphere.

Structure of the concept can be introduced as a circle in a wide meanings in the centre - basic concept nucleus of the concept, on periphery there is all introduced by culture, traditions, own and nation experience. Graphically hierarchy of the signed concepts can be presented as follows:

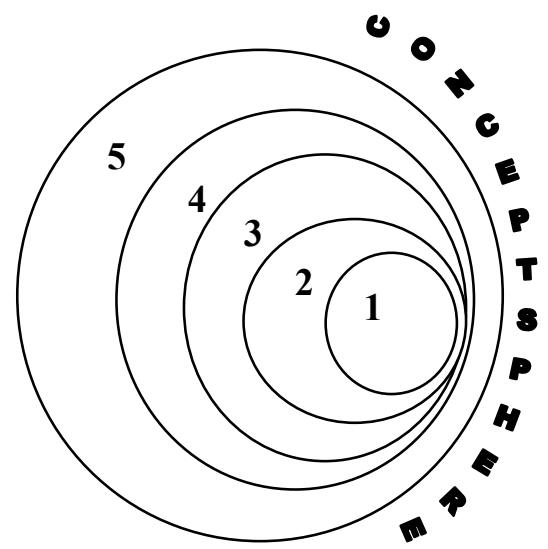

Figure 1. Concept classification on degree of semantic structures integration 
From nucleus to periphery noted by numbers

1. Superconcept: IDEOLOGY (set of ideas)

2. Macroconcept: Society ideas into reality

3. Base concept: Party (Communist) State, the USSR (Russia)

4. Microconcept: policy, economy, agriculture, science (art, sport, culture), person(-a) parties, social processes, needs, document(s) of state, state construction etc.

5. OPhC (in our case) tasted avant-garde: each communist's main business, reflection of work, fertility vitamins, gold fund of party, growth reserve, life style, leader of the proletariat and many others.

Base concepts of the cognitive linguistics make notional structure of the given research up, as conceptsphere, superconcept, macroconcept, base concept and microconcept we realize as: superconcept is a notion centre, possesses big order force and represents itself as an integration base, connected by lexical elements of general semantic (words, compound names, phrases, communicative blocks); macroconcept concept possessing more extended semantic links in frameworks formed by it and other microconcepts of conceptsphere; basic characterizing component of the superconcept, concept semantic structure of which integrates semantics of microconcepts and structure, its verbalizing lexems on various conceptual lines in the framework of the formed by it and other microconcepts of the conceptsphere, base component of the superconcept; concept, semantic structure of which integrates base concept semantics and composing microconcepts. Base concept is a concept, semantic structure of which integrates structures, it verbalizing lexems on various conceptual lines; sign of language signs, culture, law, philosophy, psychology; microconcept is a concept (a part of conceptsphere) which semantics included into the maintenance of the base concept; conceptsphere - all set of verbalized concepts, all potentialties in the whole, shown in the vocabulary of the separate person, as all language in the whole [3; 282].

Remarkable existing difference in a set of microconcepts in this or that base concept in the language material of the tested periods. For instance in language material of 1985 in the first base concept. Party underlined such microconcepts as economy, science (art, sports, culture) and properties of persons parties, which are absent in similar base concept in 1993. In base concepts of 1993, in its turn, appear microconcepts religion, person of friendly/hostile countries (Look at figures 2-4).

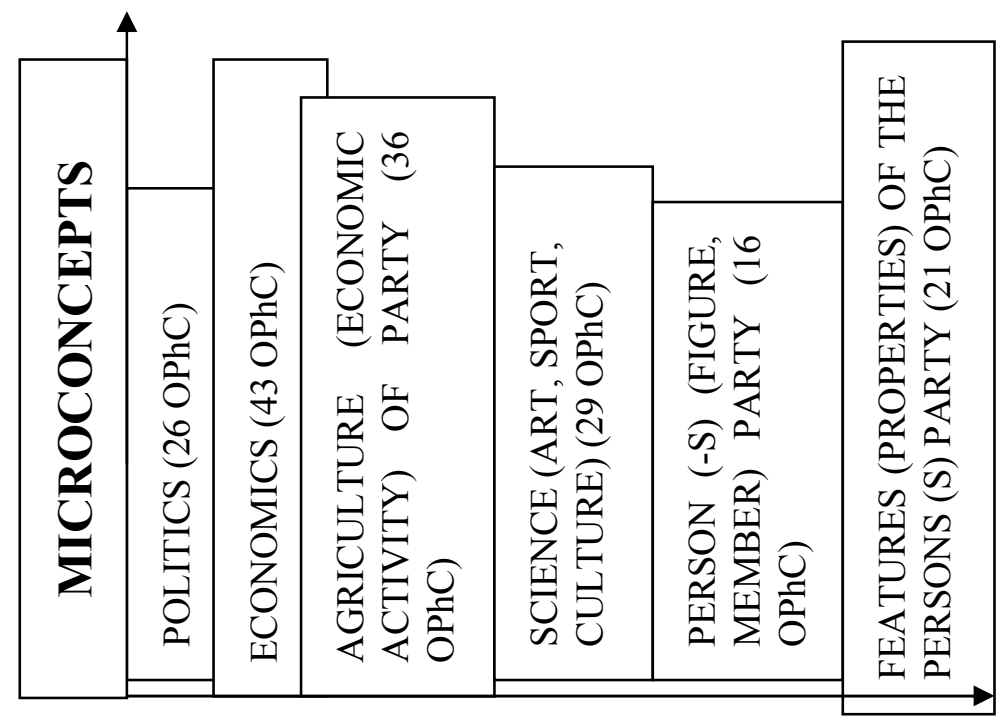

Basic concept PARTY (1985 year — only $175 \mathrm{OPhC})-3 \mathrm{OPhC} *$. * - number OPhC, synonymous basic concepts

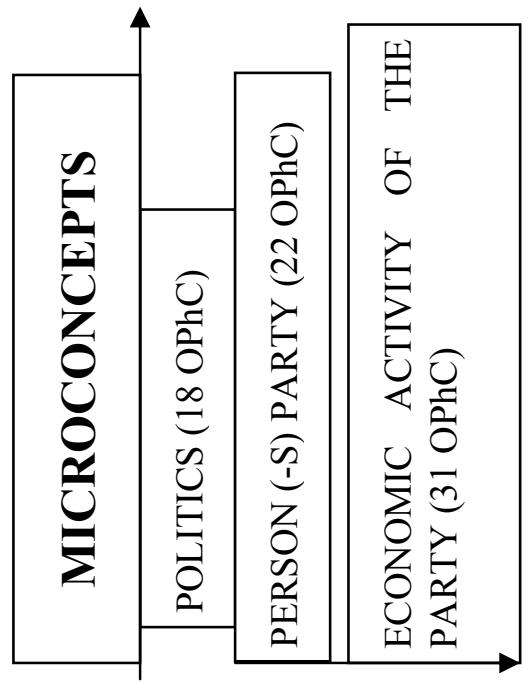

(1993 year - only $71 \mathrm{OPhC}$ ).

Figure 2. Base concept Party (1985, 1993 years)

As it seen from the 3rd figure in base concept state (1993) high frequency is turned out in microconcept economy (47 OPhC) which is explained by materials devoted to economy problems, in connection with special careful attention to economic, political sphere of the rebuilt state, in the beginning of the post soviet time. 

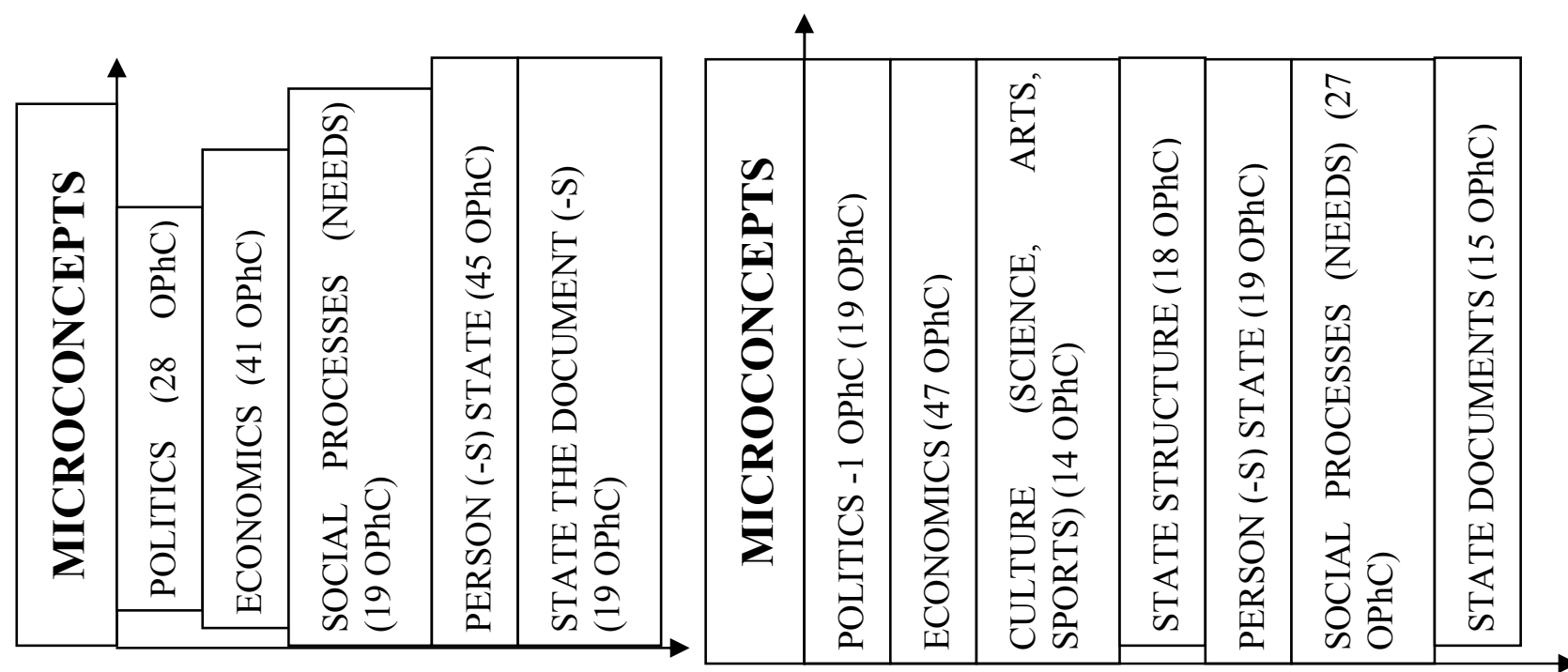

Basic concept STATE
$(1985$ year - only 153 OPhC $)-1 \mathrm{OPhC}$.

Basic concept STATE

(1993 year - only $161 \mathrm{OPhC})-2$ OPhC.

Figure 3. Presentation of the base concept State (1985, 1993 years)

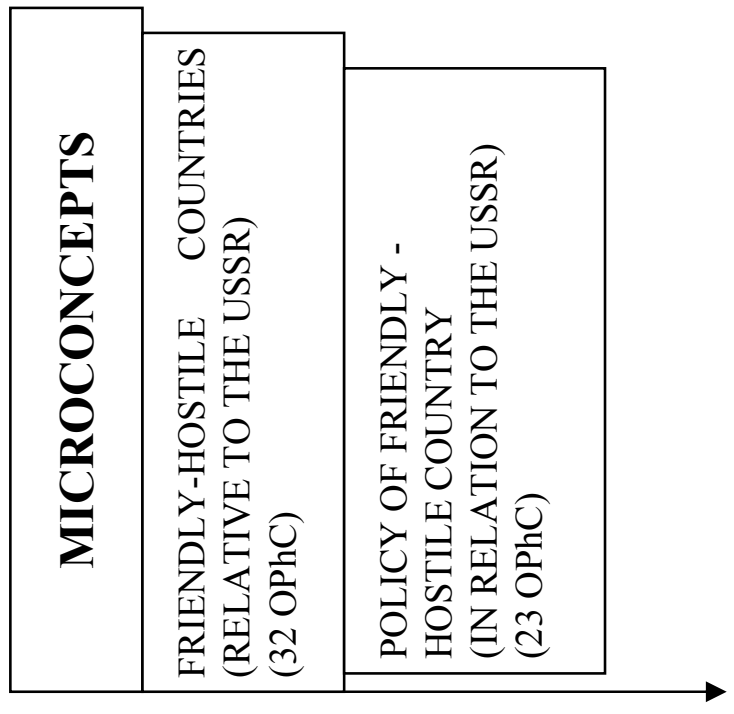

Basic concept of the USSR

(1985 year - only 62 examples) - 7 OPhC.

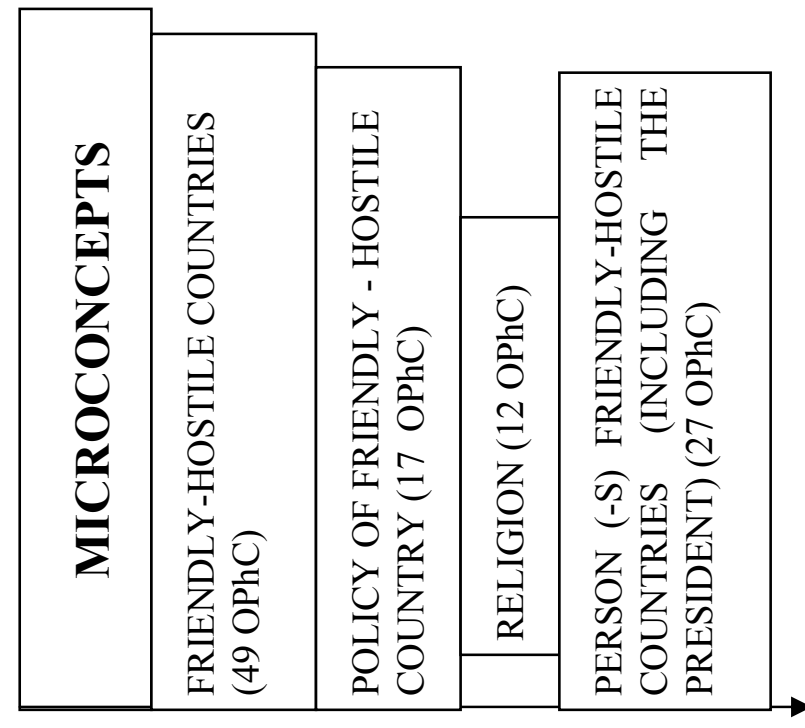

Basic concept RUSSIA (1993 year - only 111 units) - 6 OPhC.

Figure 4. Base concept USSR (Russia) (1985, 1993 years)

Apperance of this or that microconcepts in conceptsphere of the superconcept is explained by necessity of accenting and paying special attention to this or that historical state development and society. Absence of one and other microconcepts in its turn is determined by taboo for usage the Russian language development, to the whole or to some fields, on words and word combinations, no necessity - they are replaced by new others, synonymous shade and cipher objective reality resulted numerous examples taken, from the most readable, with multimillion newspapers circulations of the tested period. It is necessary to note categorical value of $\mathrm{OPhC}$ is predicted by grammatical dominating component in the result of which on the character of categorical meaning can be underlined OPhC of several types: substantive, verbal, adjective. In defining $\mathrm{OPhC}$ hidden value, in establishing transfer, lexical and grammatical status of the root component is of the great value.

In a quantitalive sense numerous was a substantive OPhC group, represented by 48 units (1985) and 107 OPhC examples (1993). For example, hell things, gold grains, slavish factories, big seven, green gold, 
steel horses, white poison, red Saturday, a solar stone, unnecessary people, elder brother, blue screens, wood athletes, blue fuel, invisible export, alive silver, orange, death etc Great amount of OPhC of the given model is known in the initial form of the nominative case. Ability/inability to form case forms depends from value and syntactic $\mathrm{OPhC}$ properties.

Among substantive $\mathrm{OPhC}$ is not less product(tive) group substantively substantive (genetive) $\mathrm{OPhC} \mathrm{(57}$ OPhC-1985, 49 OPhC-1993) Units of presented groups are regular and productive in language for example: order, observes, atlantists' creature, Neptune's reign, fertility vitamins, works' reflection, century's construction, arm-twisting, five years brakes, mankind cradle, revolution cradle, fertility powder, apartheid weapon, country of new buildings, press eyepieces, harvest law, peace keepers, innovators' party, an evil empire, a society cell and others.

Among $\mathrm{OPhC}$ substantive group special place is occupied by the group of overphrase appendices substance (single words, mainly nouns) and spread substant appendices (32 OPhC $-1985,49 \mathrm{OPhC}-$ 1993) (for example atlantists, health resorts, pioneer, wolves, pockets, a shirt, Gullivers, crumb, cream, patrol, short meetings, tormozoc (food), a dope, flyers, Cheburashka, an umbrella, a gain, shabashers, green mixture, sheep, a cribe).

In structural relation is not large $\mathrm{OPhC}$ group phaseologized overphrase combinations of the explanded design, meaning of which developed from the sum of lexical value of all expanding $\mathrm{OPhC}$ components (33 OPhC - 1985; $310 \mathrm{OPhC}-1993)$. For example: a show window of capitalism achievements, majour source of people well-being, a cradle of world revolution, avant-guard of struggle against militarism etc.

Verbal and adjective OPhC on frequency use are of low frequency, which is explained by unwillingness to use given constructions, they try to be exact, concreteness, that's was undesirable for writer in Soviet period.

This superconcept IDEOLOGY is root of world outlook component of a nation, around which is formed mankinds' world outlook. Superconcepts of a conceptsphere IDEOLOGY one of the most important society subsystem. Thus permits us to speak of conceptsphere of superconcept IDEOLOGY as of a field of functioning of more private microconcepts: «Power (political)», «state political leaders», «party» etc. Hierarchy of given concepts is dynamical and organized by versatile movement of senses, crossing them in conceptsphere limits and publicistic discourse in the whole is created under general cultural macroconcepts «own», «alien» based on opposition in different kinds, penetrating the whole culture, being one of the main concepts of the whole collective, mass, national attitude and attitude.

For analyzing specific lexical language units of the Soviet period $\mathrm{OPhC}$ - was taken for comparison language material of the newspaper «Pravda» (1993). Choice of the given period is determined by search and determining difference or similarity in structure contents of OPhC and of the early period (1985) in comparison with the material of the more recent times (1993).

Using latent phrases $\mathrm{OPhC}$ authors try to hide true state of affairs and things, using metaphors, euphemisms, periphrases etc. Attempt to shade, cipher and veil some moments, dictated by ideology demands formation of such layered to one another combinations. Perception of the text, containing OPhC can be in complete, caused by barrier of misunderstanding and vagueness for reader of such specific language, lexical units of the Soviet period as overphase combinations. Owing to OPhC explanation in context and for «wandering» as a formed sample in each text, a removal of this barrier took place.

The synonymic palette in tested material introduced in publicistic discourse let native speakes to express sense of subtle shades, to enrich author's speech by expressive emotional meaning, to create lexical background of the determined speech style party, for example, force capable to follow interests and social groups, of all nationalitics and country peoples to unit them, to mobilize people's energy for common cause of communist creation (= party) fighting avant-guard (Laos national revolutionary party), tested avant guard, inspirer and organizer of all Soviet people victories (= Communist party of the Soviet Union), party of innovators, party of future (Communist party), state (the main reformer, peoples life root «attribute» standing under society etc.).

In underlined $\mathrm{OPhC}$ tests observed such contain ironical colouring, characteristic censorship removal and in general democratization of lexics (for example, grandmother Petersburg democracy M. Salye -party political figure), great powerist (Russian chauvinist, antisemist, nationalist, demagogue) (=V.V. Zhirinovski), Clinton's left foot (= Kozyrev), a puppet, sets European capital out (the US President B. Clinton), stingy knight (= Lloyd Bentsen, the US Finance Minister), a mousetacheld top of a boot (= A. Rutskoi) etc. 
We focus attention: ideology and power in native language consciousness associated with personnel management, political leaders at the top of state system. In management there is own accurate hierarchy occupation system determines a choice of this or that nomination mean. That's why opposition «own» «strange» more brightly realized in microconcept «political leaders», «own» are those, close to the top of authorities, the centre, «strange» in turn occupies peripheral position. Antimonya «own» — «stranger's» is a cognitive universalya in nuclear part of social -political conceptsphere, introducing chrono ethnouniversal oppositional primitive. Using semantic record it is possible to present his opposition by the formulae: «Own» I estimate as good, mine (ours) won't make me (us) any harm. Other's are bad, not mine (ours) can harm me (us). Given antinomya dated back to prehistoric past and connected with the physiological instinct of self safety peculiar to living beings. Differentiation of «own», «other's» is lying on the background of cognitive and verbal levels serve mental and communicative needs of «the public person» and in this life sphere, as in any other, often take place changes of different kind (social reorientation) (rule) markers are polarized simultaneously with public events.

Differentiation connected with the USSR other's - foreign countries of non-socialist camp and their ideological supporters. At the result of existence of subjective expression of the real world picture (language and conceptual) in Soviet time erased object concept's semantics took place in the language of the Soviet epoch: concepts were exposed to subjective understanding and judgement of validity reality which dominated in the language of the Soviet period.

So the base mean of estimated connotations creation in ideologized $\mathrm{OPhC}$ of the Soviet publicistic discourse is metathor; cognitive paradigm of the base concepts change in connection with the world outlook change, defines the general development dynamics of the tested superconcept IDEOLOGY at different stages of history.

$\mathrm{OPhC}$ revealed by us is one of the brightest signs of the Russian language of the Soviet period, defining structural pecularities and conceptual office content.

\title{
References
}

1 Кубрякова Е.С. Части речи с когнитивной точки зрения / Е.С. Кубрякова. — М.: Ин-т языкознания РАН, 1997.

2 Раимбекова Б.Ж. Газетный текст на русском и казахском языках: автореф. дис. ... канд. филол. наук / Б.Ж. Раимбекова. - Алматы, 1999. - 24 с.

3 Лихачев Д.С. Концептосфера русского языка / Д.С. Лихачев // Русская лексикология. От теории к структуре текста. Антология. - М.: Академия, 1997. - С. 280-288.

\section{С.А. Баймамыров, Б.Қ. Тұңғышбаева}

\section{«Идеология» суперконцепциясының публицистикалық дискурста белгіленуі: диахрондық аспект}

\begin{abstract}
Мақалада кеңестік/посткеңестік дәуірдегі орыс тілінің жарқын белгілерінің бірі болып табылатын, әлеуметтік топтардың мүшелерінің санасында лингвистикалық өкілдік түрінде кездесетін, топтық жеке басын анықтайтын және қоғамдық-саяси лексиканың құрамына енетін «идеология» идеялық концепциясының фразеологиялық және периферикалық үйлесімдері қарастырылған. Жұмыс қазіргі лингвистикалық ғылымның өзекті мәселесіне - когнитивтік теорияға, атап айтқанда «идеология» суперконцептін құрылымдық-семантикалық зерттеуге арналған. Авторлар кеңестік және посткеңестік кезеңнің басындағы журналистік дискурста осы тұжырымдаманы вербализациялайтын орыс тіліндегі ОПХК сөз тіркестерін сипаттаған. Ұсынылған зерттеудің теориялық маңыздылығы орыс тілінің концептосфера теориясының дамуымен, авторлардың OFC теориясын, оларды ПРАГМА-лингвистикалық аспектіде реттеу, оқшаулау және сипаттау принциптерін жасауға тырысуымен анықталады. Сонымен қатар авторлар әртүрлі схемалар мен кестелерді ұсынған.
\end{abstract}

Кілт сөздер: тіл, идеология, тілдің жарқын белгілері, қоғамдық-саяси лексика, концептосфера, әлеуметтік топтар, публицистика. 


\title{
С.А. Баймамыров, Б.К. Тунгушбаева \\ Объективация суперконцепта «идеология» в публицистическом дискурсе: диахронический аспект
}

\begin{abstract}
В статье рассмотрены фразео-перифрастические сочетания в концептосфере суперконцепта «идеология», которые существуют в сознании членов социальных групп в виде языковых репрезентаций, определяют групповую идентичность и входят в корпус общественно-политической лексики, являясь одной из ярких примет русского языка советского / постсоветского времени. Работа посвящена актуальной проблеме современной лингвистической науки - когнитивной теории, в частности, структурно-семантическому исследованию суперконцепта «идеология». Авторами описаны словосочетания ОПХК русского языка, вербализующие данное понятие в публицистическом дискурсе советского и начала постсоветского периодов. Теоретическая значимость предлагаемого исследования определяется развитием теории концептосферы русского языка, попыткой авторов разработать теорию ОФК, принципы упорядочения, выделения и описания их в прагма-лингвистическом аспекте. Авторами также представлены различные схемы и таблицы, иллюстрирующие теоретические положения работы.
\end{abstract}

Ключевые слова: язык, идеология, языковые репрезентации, политическая лексика, концептосфера, социальные группы, публицистика.

\section{References}

1 Kubryakova, E.S. (1997). Chasti rechi s kohnitivnoi tochki zreniia [Parts of speech from the cognitive point of view]. Moscow [in Russian].

2 Raimbekova, B.Zh. (1999). Hazetnyi tekst na russkom i kazakhskom yazykakh [Newspaper text in Russian and Kazakh languages]. Extended abstract of candidate's thesis. Almaty [in Russian].

3 Likhachev, D.S. (1997). Kontseptosfera russkoho yazyka [Conceptsphere of the Russian language]. Russkaia leksikolohiia. Ot teorii $k$ strukture teksta. Antolohiia - Russian lexicology. From theory to text structure. The anthology. (p. 280-288). Moscow: Akademiia [in Russian]. 